\title{
THE PLACE OF LISTENING IN THE L2 CURRICULUM: A REVIEW
}

\author{
Tri Wahyuni Floriasti \\ Yogyakarta State University
}

\begin{abstract}
In second language research, listening opportunities are often characterized as the linguistics environment - the stage for SLA. This environment, that is, the speakers of the target language and their speech to the L2 learners, provide linguistics input in the form of listening and interaction opportunities embedded in social and pedagogic situations. It has been noted that for a person to learn second language three major conditions are required: (1) a learner who realizes the need to learn the second language and is motivated to do so, (2) Speaker of the target language who know it well enough to provide leaner with access to the spoken language and that support (such as simplification, repletion, and feedback) they need for learning it; and (3) a social setting which bring the leaner in frequent enough and sustain enough contact with target language speakers to make language learning possible. Listening is required in two of these conditions, and is therefore an essential means of language development, a point that is often overlooked in language pedagogy and research. The learner, in order to acquire the language, must come to understand the input and pay attention to the forms in the input. The more students get input from listening, the richer the knowledge they acquire then the more fluent they become. It is educator who need to design and place listening in the right position so that it can bring the leaner in frequent enough and sustains enough contact with target language speakers to make language learning possible.
\end{abstract}

Keywords: Listening, L2 curriculum

\section{INTRODUCTION}

This article calls for a reviewing of the position of listening lesson in the curriculum. Before we do anything else, therefore, it is important to try and gets as clear as possible what it is that we will be discussing under definition of listening and overview of listening comprehension studies. 


\section{Definition of Listening}

What is listening? Rost $(2002,1)$ says in the 1920s and 1930s with advancing knowledge of human brain, listening was defined as a largely unconscious process controlled by hidden cultural 'schemata'. In the 1940s, when advances in telecommunications were exploding, and information-processing was seen as the new scientific frontier, listening was defined in terms of successful transmission and recreation of 'messages'. In the 1950s when computer science began to dominate, listening was defined in terms of analyzing and tagging input so that it could be stored and retrieved efficiently. In the 1960s, with the raise of transpersonal psychology, listening included heuristics for understanding the intent of the speaker.

The definition keeps changing depend on the trend. It can be assumed that other interest influence the definition of listening. With the renewed interest in anthropology in the 1970s, definitions of listening as a interpreting the cultural significance of 'speech behavior' gained acceptance. In the 1980s and 1990s, with the advances in computer software for dealing with vast quantities and types of data, listening came to be defined as parallel processing of input. And you? What is listening?

\section{Overview of Listening Comprehension Studies}

Although listening is now comprehended as a critical dimension in language learning, it still gives puzzle in understanding the processes. Listening gets little attention compare to the other three skills (reading, writing and speaking), which get more attention. Teachers often expect students to develop their listening skill by osmosis and without help (Mendelsohn, 1984; Oxford, 1993 in Osada, 2004). In the osmosis approach, also known as the Audiolingual method, it is believed that if students listen to the target language all day, they will improve their listening comprehension skills through experience.

The roots of audiolingualism lie in the early years of the 20 s century, and had a significant influence on theories of language teaching. Behaviorist drew inspiration from Pavlov's conditioning experiments - stimulus and response. This traditional approach to listening, which treated it as an enabling skill for production-oriented activities, "has trapped students in a frenzied 'Hear it, repeat it!', 'Hear it, answer it!', or 'Hear it, translate it!' nightmare"' (Meyer, 1984, p. 343 in Osada, 2004, p. 54). 
Arguments keeps coming and changing the comprehension of listening. It began to be expressed in the mid-1960s by Rivers who had enough foresight to say that, "Speaking does not of itself constitute communication unless what is being said is comprehended by another person (p. 196), and that "teaching the comprehension of spoken speeches is therefore of primary importance if the communication aim is to be reached" (p. 204) in Osada (2004). According to Field (1998, p. 110), in the late 1960s and early 1970s, listening comprehension lessons followed a relatively consistent format.

More attention grows to listening in 1980s and 1990s. During the 1980s, explorations of intricacies of this complex skill, more research, and curriculum development on listening comprehension were done, and they continue dramatically in 1990s. Throughout the 1990s, attention to listening in language teaching and aural comprehension in second language or foreign language acquisition became an important area of study (Osada, 2004, p.55).

\section{DISCUSSION}

Listening has been neglected or poorly taught may have stemmed from the belief that it is a passive skills (Call, 1985) in Osada, 2004, p.54 and Nunan (2003). It has been noted that for a person to learn second language three major conditions are required (Rost, 2002, p.90-91): (1) a learner who realizes the need to learn the second language and is motivated to do so, (2) speaker of the target language who know it well enough to provide leaner with access to the spoken language and that support (such as simplification, repletion, and feedback) they need for learning it; and (3) a social setting which bring the leaner in frequent enough and sustain enough contact with target language speakers to make language learning possible. Listening is required in two of these conditions, and listening opportunities are often characterized as the linguistics environment - the stage for SLA. This environment, that is, the speakers of the target language and their speech to the L2 learners, provide linguistics input in the form of listening and interaction opportunities embedded in social and pedagogic situations.

Krashen (1982), Dunkel (1991) maintained the comprehensible input was a necessary condition for language learners. One investigation from Dupuy (1999) in Nation (2009) about "narrow listening" - an approach based on Krashen's idea, reported improvements in students listening comprehension, fluency, and vocabulary as well as increased confidence in French. The improvements were 
resulted from listening as many times as they wish to a range of $1-2$ minute aural texts on a range of familiar and interesting topics. Rickerson (1984) in Dunkel (1991, p. 437) stresses the need to provide foreign/second language students with opportunity to produce the language to enhance the motivation during language learning. Thus, in order to be able to demonstrate meaningful meaning, students need to get relevant and comprehensible input either from listening or reading so that they acquire not only full understanding of the messages being spoken but also the model to communicate them in the appropriate speaking context. Rivers (1966) in Osada had enough foresight to say that, speaking does not itself constitute communication unless what is being said is comprehended by another person (p.196), and that teaching the comprehension of spoken speeches is therefore of primary importance if the communication aim is to be reached' (p.204). The more students get input from listening, the richer the knowledge they acquire then the more fluent they become.

As teachers and scholars grow to understand the unique characteristics of the listening skill and the significant role it plays in language learning and communication, they recognize more and more the importance of teaching listening comprehension (Rubin 1994, p.199). To comprehend spoken messages, listeners may need to integrate information from a range of sources: phonetic, phonological, prosodic, lexical, syntactic, semantic, and pragmatic (Osada, 2004, p.55-56). The fact that we achieve all this in real time as the message unfolds makes listening "complex, dynamic, and fragile" (Celce-Murcia, 1985, p.366). The learner, in order to comprehend then reply the spoken messages, as speaking is fundamentally an interactive tasks and it happens under real-time processing constrains (Hughes, 2004, p.135) and (Buck, 2001), must come to understand the input and pay attention to the forms in the input. Recognizing words in fluent speech is the basis of spoken-language comprehension.

The two main tasks of listener in word recognition are identification of words and activating knowledge of word meanings. Word recognition is often the most problematic process of listening. Further, if a listener recognizes a word but has limited or no knowledge of its basic meaning, the entire process of word recognition is subverted, and the listener must resort to compensatory strategies for understanding (Rost, 2002, p.20). Berne in Osada (2004) points out fact that training in the use of listening strategies facilitates L2 listening comprehension and L2 learners can and should be taught how to use listening strategies. In addition, the 
use of pre-listening activities, particularly those that provide short synopses of listening passage or allow listeners to preview to the comprehension questions, facilitate L2 listening comprehension. In line with that, Field (1998, p.110 and 2009, p.17) proposes pre-listening activities, during listening and post-listening, and Buck 1995 in Nunan (2003, p. 29) states that pre-listening activities to do two things: provide a context for interpretation and activate the background knowledge which will help interpretation.

Spoken language is very different from written language. Buck (2001) points out that there are three characteristics of speech that are particularly important in the listening comprehension construct: (a) speech is encoded in the form of sound; (b) it is linear and takes place in real time, with no chance of review; and (c) it is linguistically different from written language. When we consider the complex nature of speech interaction as it happens in real time, it is perhaps unsurprising that even the most advanced students still feel most at a loss when they are trying to take part in spontaneous, informal conversation in a new language (Hughes, 2002, p.134). McCarthy and O'Keeffe (2004, p. 33) proposes according to Burns, focus on the microstructures of conversation and can offer teachers the opportunity to highlight for students the appropriateness of utterances, how speakers negotiate certain situations (e.g., accepting/rejecting invitations) as well as providing a framework for the performance of speech acts, for example, through role plays and simulations. Meanwhile, due to the interconnection between listening and speaking, it is also important to set different types of speech modifications or visual aids varies according to the degree of L2 listening proficiency (Berne in Osada, 2004, p. 55-56) and Field (2009, p.18) presents it is important to compensate for the limitations of using an audio cassette by giving students a general idea of what they are going to hear.

Studies have suggested visual support can enhance listening comprehension. Rubin (1994, p.204) found that the listening comprehension of high-beginning Spanish students who watched dramas on video improved significantly over students who received no video support for their listening training. She argues "video can serve as a haven to enhance listening comprehension if it is selected so that it provides sufficient clues for information processing". Herron et.al., reported that for first-year university French students listening comprehension improved more after one year's exposure to a video-based curriculum than after the same length of exposure to a text and audio-based 
curriculum. Further clarification of when and how video can help is provided by Mueller's study of English-speaking students of German. Mueller showed that when the text is an interview, with a single, visual line drawing, the helpfulness of visual clues is inversely related to proficiency levels-i.e., the more proficiency the learner, the less crucial the visual aids are for comprehension. Wolff's study of German ESL learners between ages twelve and eighteen found that the more difficult the text was, the more subject used the illustration.

It is important to note that each individual process may produce imperfect or erroneous recognition of the words in an utterance. Fortunately, spoken language comprehension can usually continue successfully even if all words are not recognized because the listener can make inferences about the meaning of utterances through illustration in the task (Rost, 2002, p. 20-21). In Rubin (1994, p.205-206), Lund also looked at how task type affects learners' ability to remember more main ideas or details and to give more inferences and elaborations. Lund notes "the result of the study do not necessarily indicate that one task is superior to another. It all depends on the objectives for listening" p.14. The study shows that learners do modify their behaviour depending on the task they are given. It is also need to be considered activities based around speaking need to be managed and fostered through careful planning and direction by the teacher, and through a choice of suitable tasks to stimulate speech (Hughes, 2002, p.134).

\section{CONCLUSION}

It can be seen from the intertwined connection between speaking and listening, and culture. In addition, listening strategies, awareness of spoken language, media visual, task characteristics, amount of comprehensible input and opportunities for listening and speaking are significant components in this research study. Thus, It is educator who need to design and place listening in the right position so that it can bring the leaner in frequent enough and sustains enough contact with target language speakers to make language learning possible.

\section{REFERENCES}

Anderson, Mark. Anderson, Kathy (1998). Text Types in English 2. 1. ed. South Yarra: MacMillan Education Australia PTY LTD.

Buck, G. (2001). Assessing listening. New York: Cambridge University Press. 
Dunkel, Patricia. (1991). Listening in the Native and Second/Foreign language: toward an integration of research and practice. TESOL QUARTERLY, Vol. 25, No. 3, Autumn 1991.

Dwight Atkinson, (1997). A critical approach to critical thinking in TESOL. TESOLQUATERLY Vol.31, No. 1, Spring 1997.

Field, John. (2009). Listening in the Language Classroom. Cambridge: Cambridge University Press.

Field, John. (1998). Skills and Strategies: towards a New Methodology for Listening. ELT Journal Volume 52/2/April 1998. Oxford University Press.

Floriasti, Tri Wahyuni, "Developing Character building through multicultural reading text”, Proceeding Presented at International Seminar ACLL Osaka, Japan, April 28, 2012

Hughes, R., (2002). Teaching and researching speaking. Longman, London

Lee, Anita. (1999). The Multicultural Curriculum: Toward Education for Peace and Development. SEAMEO-Jasper Fellowship Monograph 1999 Series 8. http://www.seameo.org/v/library/d l we $1 \mathrm{come}$ /publications/ebook/jasper/series8/series8-2.htm. February 24, 2011.

McCarthy, Michael., O'Keeffe, Anne ., (2004). Research in the Teaching of Speaking. Annual review of applied linguistics 24, 26-43. Cambridge University press

Nation, I.S.P. \& Newton, J. (2009). Teaching ESL/EFL Listening and Speaking. New York: Routledge

Nunan, David. (2003). Practical English Language Teaching. New York: McGraw-Hill

Nobuko Osada, (2004). Listening comprehension research: A brief review of the past thirty years. Dialogue journal, 2004, Vol, 3, pp. 53-66, ISSN 13495135

Ratna Megawangi (2004). Pendidikan Karakter solusi yang tepat untuk membangun bangsa. 1. ed. Jakarta: Star Energy.

Rost, M., (2002). Teaching and researching listening. Longman, Harlow, England; New York

Rubin, Joan. (1994). A review of second language listening comprehension research. The modern language journal, 78, ii (1994) 0026-7902/199-221 